\title{
Numerical and experimental models applied to an ogee crest spillway and roller bucket stilling basin
}

\section{Modelagem numérica e experimental aplicada a um vertedouro de superfície composto por um perfil Creager e um dissipador do tipo roller bucket}

\author{
Vitor Hugo Pereira de Morais $^{1}$ (D), Tiago Zenker Gireli ${ }^{1}$ (D) \& Paulo Vatavuk $^{1}$ (iD \\ ${ }^{1}$ Universidade Estadual de Campinas, Campinas, SP, Brasil \\ E-mails: vhmorais@gmail.com (VHPM), zenker@fec.unicamp.br (TZG), pvatavuk@fec.unicamp.br (PV)
}

Received: February 12, 2019 - Revised: November 08, 2019 - Accepted: January 23, 2020

\begin{abstract}
Traditionally, reduced physical models are used to allow control, instrumentation and experimental evaluation of flow. More recently, computational fluid dynamics (CFD) has emerged as a tool that allows numerical modeling of flows and can complement the information provided by the physical model. The objective this paper is to validate the CFD tool in reproducing the flow through an ogee crest spillway with a roller bucket stilling basin. This validation was performed with the data from a reduced scale experiment in which measurements were made of the position of the water free surface and of the pressure loads in the spillway profile. It was verified that the CFD tool is suitable for the study of this type of flow, being able to reproduce the experimental results. In the execution of the numerical simulations, special attention was given to the influence of the mesh on the results. An important influence of the mesh was observed in some results, which shows the importance a sensitivity analysis of this parameter when performing CFD simulations. The obtained results offer the prospect of using CFD as a supporting tool for the design of spillways and stilling basins.
\end{abstract}

Keywords: Physical scale model; Computational fluid dynamics; Ogee crest spillway and roller bucket stilling basin.

\section{RESUMO}

Tradicionalmente utilizam-se modelos físicos construídos em escala reduzida de modo a permitir o controle, instrumentação e avaliação do escoamento. Mais recentemente a fluidodinâmica computacional (CFD) tem surgido como uma ferramenta que permite modelar, de forma numérica, os escoamentos, podendo complementar as informações fornecidas pelo modelo físico. O objetivo deste trabalho é validar a ferramenta de fluidodinâmica computacional (CFD) no escoamento sobre vertedouro do tipo Creager e dissipador roller-bucket. Esta validação foi feita com os dados de um experimento em escala reduzida em que foram feitas medições da posição da superfície livre da água e das cargas de pressão no perfil do vertedouro. Verificou-se que a ferramenta de CFD é adequada para o estudo deste tipo de fluxo, sendo capaz de reproduzir os resultados experimentais. Na execução das simulações numéricas foi dada uma atenção especial à questão da influência da malha nos resultados. Foi observada uma influência importante da malha em alguns resultados, o que mostra a importância de uma análise de sensibilidade deste parâmetro ao realizar as simulações de CFD. Os resultados obtidos oferecem a perspectiva de uso da modelagem CFD como ferramenta de suporte ao dimensionamento de vertedouros e bacias de dissipação de energia. O trabalho desenvolvido oferece a perspectiva de simular o escoamento na escala real utilizando CFD, sem que ocorram os erros associados aos efeitos de escala inerentes aos modelos reduzidos.

Palavras-chave: Modelo físico reduzido; Fluidodinâmica computacional; Vertedouro perfil Creager; Dissipador roller bucket. 


\section{INTRODUCTION}

In the design of hydraulic works the adequate dimensioning is fundamental to guarantee the correct operation and the safety of the structure. Due to the complexity of the flow, the use of reduced-scale physical models in hydraulic structure projects, besides being a traditional solution, is also considered the most reliable method to reproduce complex hydraulic phenomena.

However, the use of reduced physical models involves methodological simplifications as the neglect of the viscous forces of the flow (Motta, 1972). In addition, the influence of limits inherent to the construction of the models, such as the need to include adjacent walls not present in the prototype, can be mentioned.

More recently, numerical approaches using Computational Fluid Dynamics (CFD) have also been successfully validated to simulate complex hydraulic phenomena by two main methodological approaches. In both, the CFD model is created in real scale (1:1), but the data set used to validate the model, for the first one, comes from the prototype instrumentation and for the second one, is based on the results obtained in reduced physical models and extrapolated by similarity criteria for the scale of the prototype.

In the group of studies that validate numerical models using prototype data, it can be mentioned (Gessler, 2005; Turan et al., 2008; Zeng et al., 2016). This approach can be considered expensive and complex because of the instrumentation system to be used in large hydraulic works, besides the impossibility of controlling the sampled scenarios, including extreme scenarios that are rare and the most worrying for structure safety.

On the other hand, in the conception and application of reduced physical models it is necessary to adopt incomplete similarity criteria to attain a relationship between two phenomena (model and prototype). This association in fluid mechanics is usually the relation between a real-scale and a reduced-scale surface flow (Shames, 1973). The following works compared CFD results with those obtained from reduced scale physical models extrapolated to the real scale by Froude similarity criteria (Savage \& Johnson, 2001; Rodrigues, 2002; Dargahi, 2006; Johnson \& Savage, 2006; Aydin \& Ozturk, 2009; Pelletier, 2010; Dettmer et al., 2013).

Furthermore, predictions extracted from the model may be affected by a certain error as a result of the fact that it is impossible to achieve simultaneous equality in the prototype and in the model of all the dimensionless groups that intervene in the phenomenon (Reynolds, Froude and Weber). This type of error is called scale effect (Motta, 1972) and is one of the causes of the observed deviations when comparing physical and numerical models using this methodology. In this way, a methodology premise of this study is the definition of a numerical model based on the physical characteristics used in the built-in reduced-scale hydraulic model, i.e., results obtained in both systems can be directly evaluated and compared. Thus, making the comparison free from the uncertainty associated to the scale-effect. This important methodological hypothesis was not found in works of this nature. Furthermore, none of the located references evaluated spillways with roller bucket type stilling basins.

Therefore, the objective of this paper is to validate the CFD tool in reproducing the flow through an ogee crest spillway with a roller bucket stilling basin. The validation is done by the direct comparison with the reduced scale model and is based in the water depths (waterline profile), pressures imposed by the flow to the structure and velocities at stilling basin. Furthermore, this paper also focus on the qualitative evaluation of the computational model response to the turbulent characteristics of the discharge in the energy dissipation region.

\section{MATERIALS AND METHODS}

To achieve the purposes of this study, the physical and numerical models were tested with flow rates equal to $0.016 \mathrm{~m}^{3} / \mathrm{s}$ and $0.177 \mathrm{~m}^{3} / \mathrm{s}$, corresponding to the minimum and maximum flow rate of the spillway in the reduced scale of the reduced scale model. These values represent extremes discharges of the modeling test range. In Figure 1 it is possible to observe the geometry of ogee crest spillway and roller bucket dissipator which was modeled.

\section{Physical model}

The two-dimensional (2D) and sectional physical model of the spillway with 1:60 scale that serves as a basis for this study, was built at the Fundação Centro Tecnológico de Hidráulica - FCTH (Technological Center of Hydraulics Foundation) of the University of São Paulo, Brazil. The 2D channel is 15 meters long, $0.75 \mathrm{~m}$ wide, and $0.75 \mathrm{~m}$ high. In studies of this nature, the objective is to evaluate hydraulic behavior in a typical spillway span between two piers. Hence, two spans were represented as shown in Figure 2. An entire and a central span where the results were collected and two halves of a spillway span in adjacent positions to reduce the interference of the side walls of the model in the surface flow. At this point, it is important to emphasize that the physical model tests were conducted on a free flow spillway and without gate control.

The physical model-based measurements of output flow were performed by a triangular weir located at the output of the channel, where the height of the water column above the spillway vertex is considered the determining factor of the flow in transit. For this measurement system, the errors associated with the defined

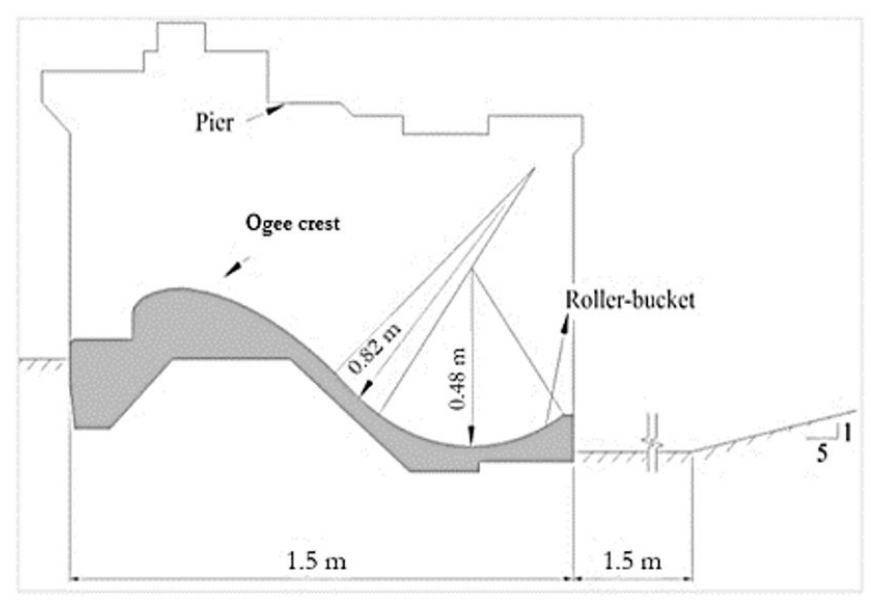

Figure 1. Geometry of ogee crest spillway and roller bucket dissipator. 
flow rates are $\pm 0.000120 \mathrm{~m}^{3} / \mathrm{s}$ and $\pm 0.000531 \mathrm{~m}^{3} / \mathrm{s}$, respectively for minimum and maximum modeled flows. Due to the water level fluctuations resulting from the turbulent flow, mainly in the energy dissipation region, and to ensure greater accuracy in the recording of water level, a capacitive tip interconnected to a data acquisition system was used to enable the data to be record for a predetermined time and frequency $(300 \mathrm{~s}$ and $30 \mathrm{~Hz})$. The error associated with the use of the capacitive tip can be attributed to the static error, i.e., to the variation of the voltage to a stagnant condition of the water level. This error can be attributed to electrical interferences and external interferences (vibrations, wind, etc.) can be attributed to this error. Therefore, the error assumed in determining the displacement of the water level was $\pm 0.001 \mathrm{~m}$. Figure 3 displays the locations where free surface positions along the channel were obtained. The sections were equidistant at $0.50 \mathrm{~m}$ (d) and labeled from (E-6) to (E6).

The magnitude of velocities was obtained at section (E1) using a micro current-meter at the points showed in Figure 4a. The nomenclature of the measuring points (0.02-0.24) refers to the vertical distance, in meters, from the local bottom. The micro current-meter is basically composed of a rod containing a propeller and a recorder (meter). Similar to the capacitive tip, the micro current-meter is connected to a data acquisition system that records the number of propeller rotations for a pre-set period (120 s) which is transformed into flow velocity through the instrument calibration curve. The calibration of the used micro current-meter resulted in $\mathrm{a} \pm 0.03 \mathrm{~m} / \mathrm{s}$ uncertainty.

In the Figure $4 b$, it is possible to verify the location of the piezometers installed along the spillway and stilling basin profiles, totaling 17 pressure measurements. A piezometric frame with $\pm 0.001 \mathrm{~m}$ error was used to obtain the pressure loads on the structure.

\section{Numerical model}

The FLOW-3D ${ }^{\circledR}$ computational package was used. As in all CFD programs, the flow domain is divided into small volumes called cells. The software solves the Reynolds-averaged Navier-Stokes (RANS) equations using the finite volumes method (FVM), is a numerical method that imposes the conservation of the properties at elementary volumes.

FLOW-3D ${ }^{\circledR}$ is a wide-ranging software used to represent turbulent and free surface flow. This software allows three-dimensional
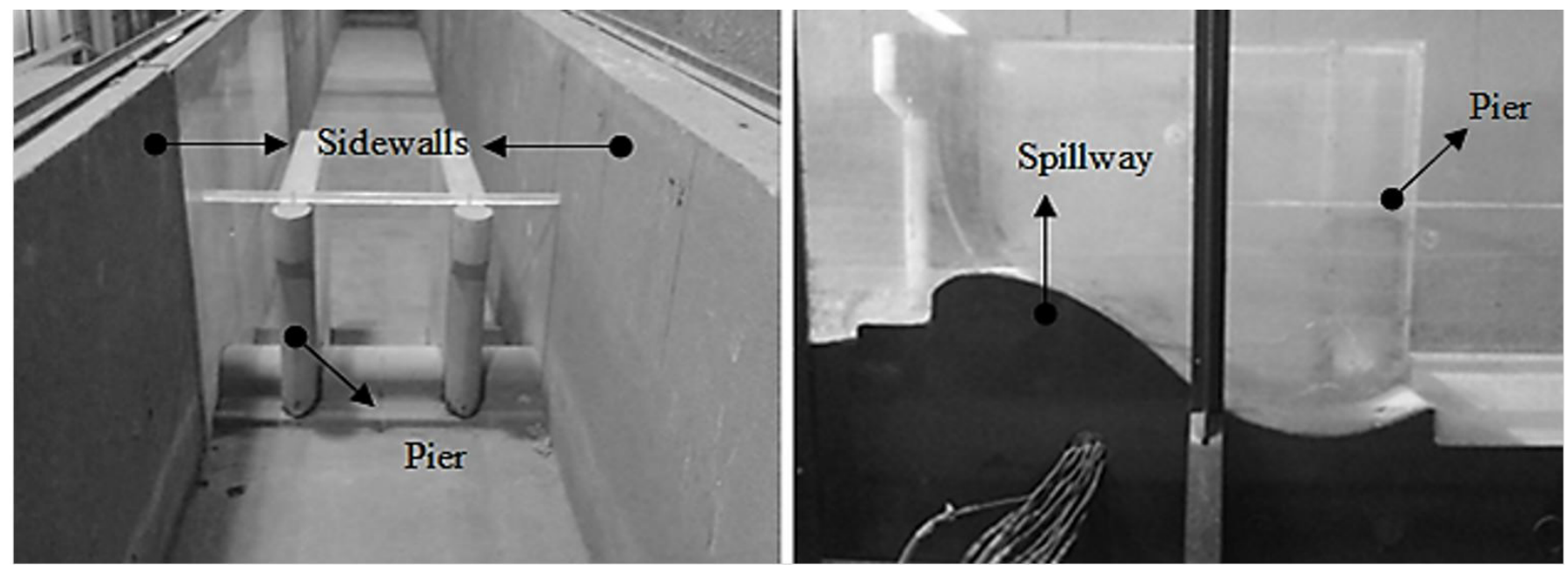

Figure 2. Physical model upstream view (left) and side view (right).

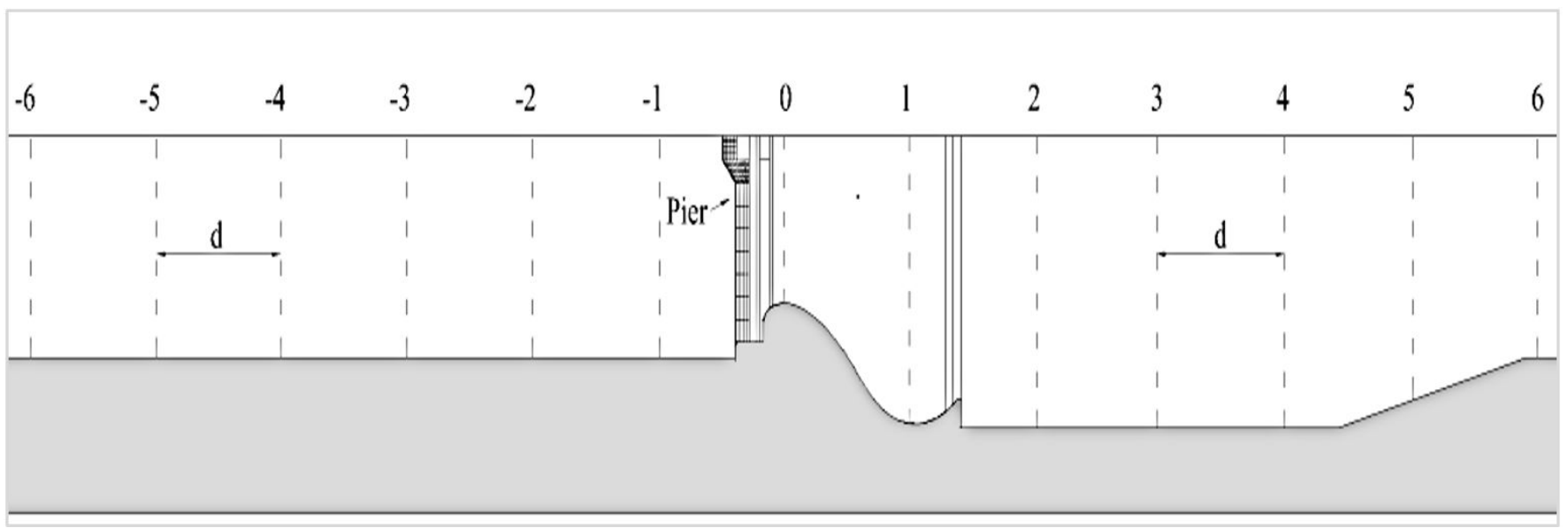

Figure 3. Sections of water level measurement. 


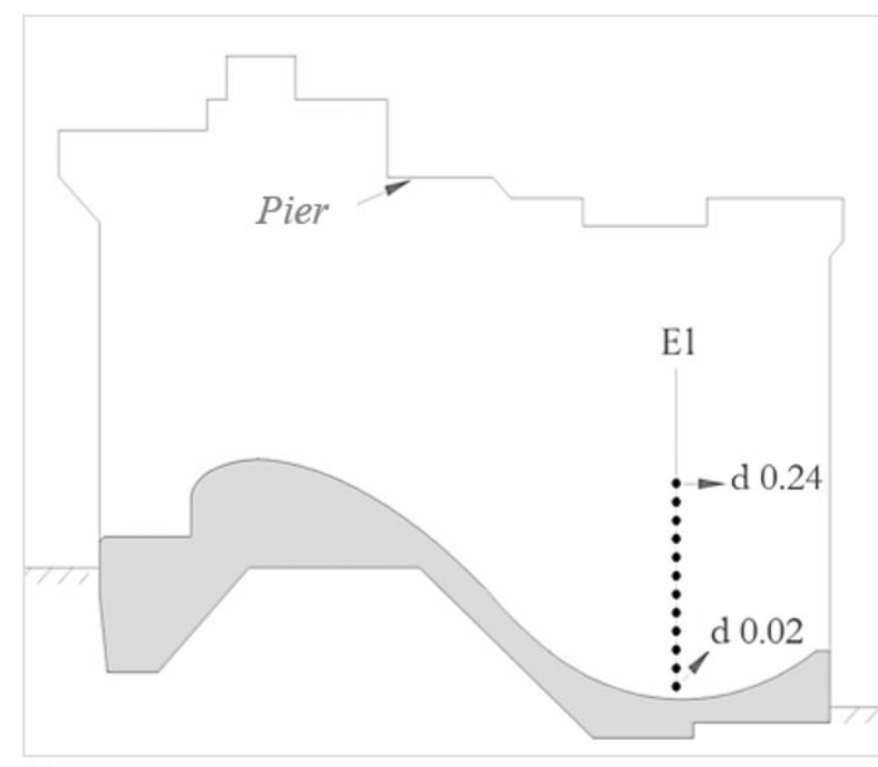

(a)

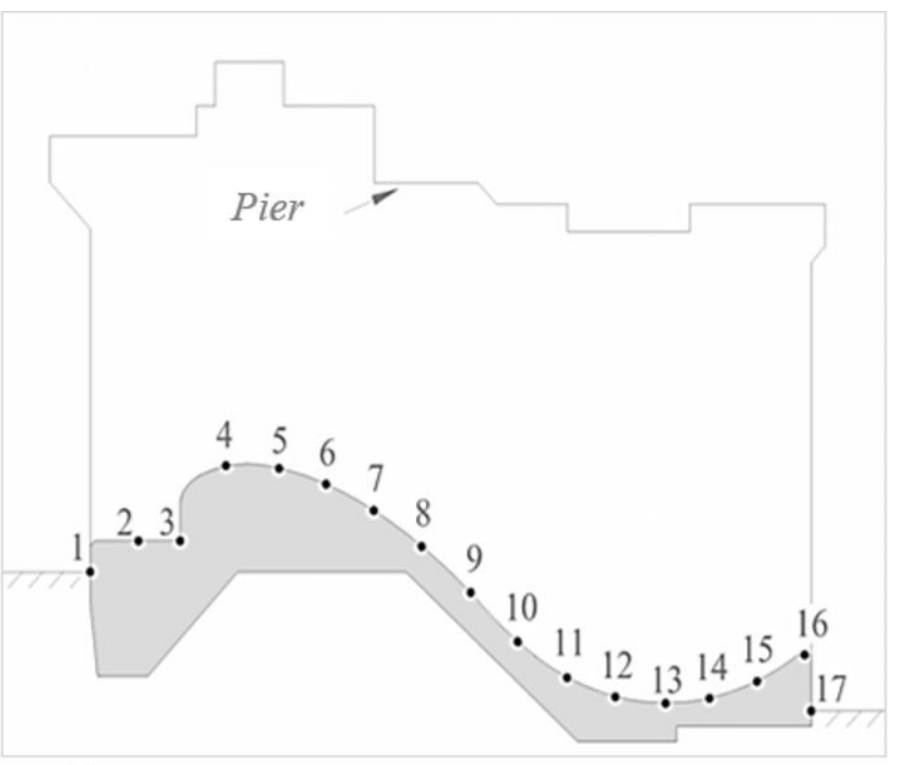

(b)

Figure 4. Location points of velocity measurements (a) and positions of piezometers (b).

(3D) flow simulations of compressible and incompressible fluids in a steady-state or transient regime and with complex solid contours. For each cell in the computational mesh, average pressure values and velocities are computed and discretized during simulation period using the staggered mesh technique (Versteeg \& Malalasekera, 1995).

FLOW-3D ${ }^{\circledR}$ has several models of calculation that can be activated by the user to meet hydraulic characteristics. In this work the gravity and the turbulence models were used. The first one is the most basic of the models and is responsible for enabling the forces of inertia and the second allows the characterization of turbulence through specific turbulence modes. Here, the standard $\mathrm{k}-\varepsilon$ turbulence model was used, it is based on model transport equations for turbulence kinetic energy $(\mathrm{k})$ and its dissipation rate $(\varepsilon)$ (Launder \& Spalding, 1972). According to Tadayon \& Ramamurthy (2009), Aydin \& Ozturk (2009), Naghavi et al. (2011), Dettmer et al. (2013) and Zeng et al. (2016), the k- $\varepsilon$ turbulence model has shown satisfactory results, furthermore, it offers a good compromise between computational effort and numerical precision.

The representation of the solid contours is performed using the FAVOR method (Fractional Area Volume Obstacle), outlined by Hirt \& Sicilian (1985). This is a porosity technique used to define obstacles in which the porosity of the grid assumes a value equal to 0 within the obstacle and value equal to 1 out of it. Cells partially populated with the obstacle receive values between 0 and 1 depending on the percentage occupied by the obstacle.

Location of the interface in each cell is defined as a first-order approximation and represented through 3D planes. Cutting plane defines volume fraction of each cell and area fraction (Ax, Ay, and Az) on each cell face in which the surface flow can occur. In summary, the representation of the geometry to be studied is defined by a series of facets formed by the intersection between the computational mesh and the reproduced geometry.

Hence, it becomes obvious that smaller the size of the cell, smaller the interference. Also, the representation of the contour of the obstacle will be closer to the original geometry. It is noteworthy that although smaller cells estimate the representation of the contour this method gives only an approximate representation of a curved surface.

Numerical results were obtained for four different mesh sizes (M1, M2, M3, and M4) for improved computational results and subsequent validation. Table 1 shows the characteristics of the computational simulations used. In Figure 5 displays the result of the FAVOR method applied to different discretization of the computational mesh to illustrate its effects on the representation of modeled geometry. It is noticeable that the setting presented to the right (M4) of Figure 5 resulted in a more faithful representation of the geometry when compared to the one presented to the left (M1). It is important to highlight that the better representation of the geometry leads to the increase of number of mesh elements and consequently increases the processing time of the numerical solution (Morais, 2015). However, it is up to the user to evaluate to what extent this improvement brings benefits to the results.

In relation to the roughness attributed to the physical limits of the computational model, a roughness of $0.002 \mathrm{~m}$ and $0.0004 \mathrm{~m}$ was considered for the channel (bed) and lateral walls and for the profile and piers of the spillway, respectively.

Figure 6 illustrates the geometry set in the numerical model without the presence of the side walls to simplify viewing. Figure 7 illustrates the design of the computational mesh used. Two mesh blocks were used, the first one represents the water inlet and the second one represents the channel. Figure 7 also indicates boundary conditions which were used: (W) indicates a Wall; (C) is a continuity condition between the blocks; $(\mathrm{P})$ is a constant pressure due to the atmosphere, $(\mathrm{Q})$ is the volume flow rate inlet.

In FLOW-3D ${ }^{\circledR}$, the collection of results can be accomplished by means of baffles and history probes. Baffles are $2 \mathrm{D}$ surfaces and have simple shapes like planes, cylinders, cones, and spheres. They can be porous and non-porous and can be used to measure mass flows, heat streams, and applied forces. Baffles were used 
in this study to obtain flow rate. Transit flow is directly obtained from the section where the baffle is located and is related to the number of elements of the computational mesh.

History probe is a tool used to collect parameters at the exact location of a probe or corresponding section. Each probe calculates and stores all relevant quantities of the simulation. Here, the probes were used to collect the height of the water column in the reference sections and the average pressures along the spillway and stilling basing profiles (piezometers). Figure 8 illustrates the general layout with the location of theses result collecting tools.

Table 1. Characteristics of computational simulations.

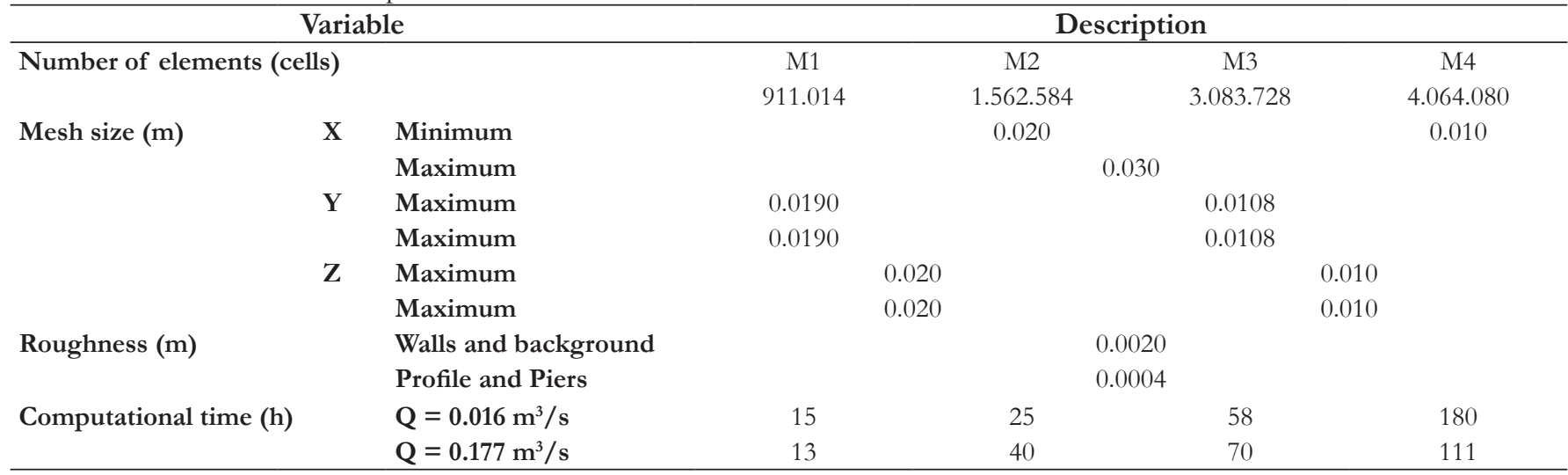
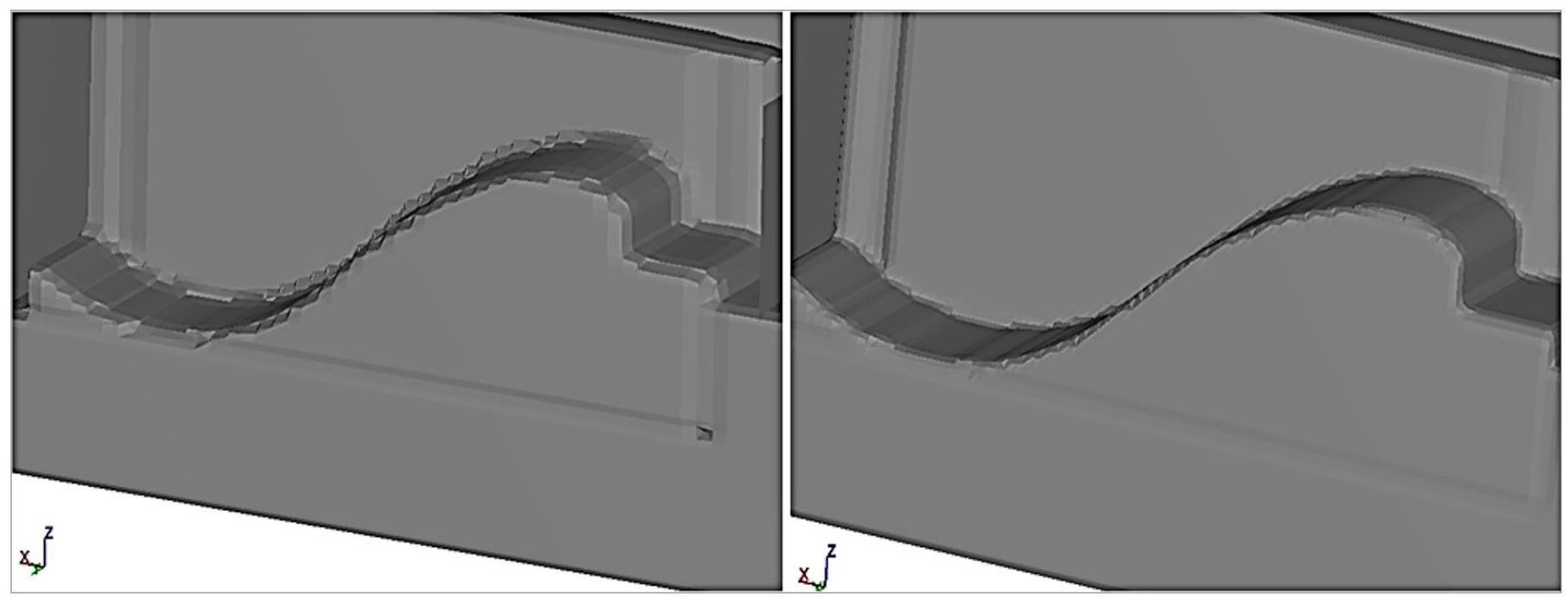

Figure 5. FAVOR Method-lower discretization (left) and higher discretization (right).

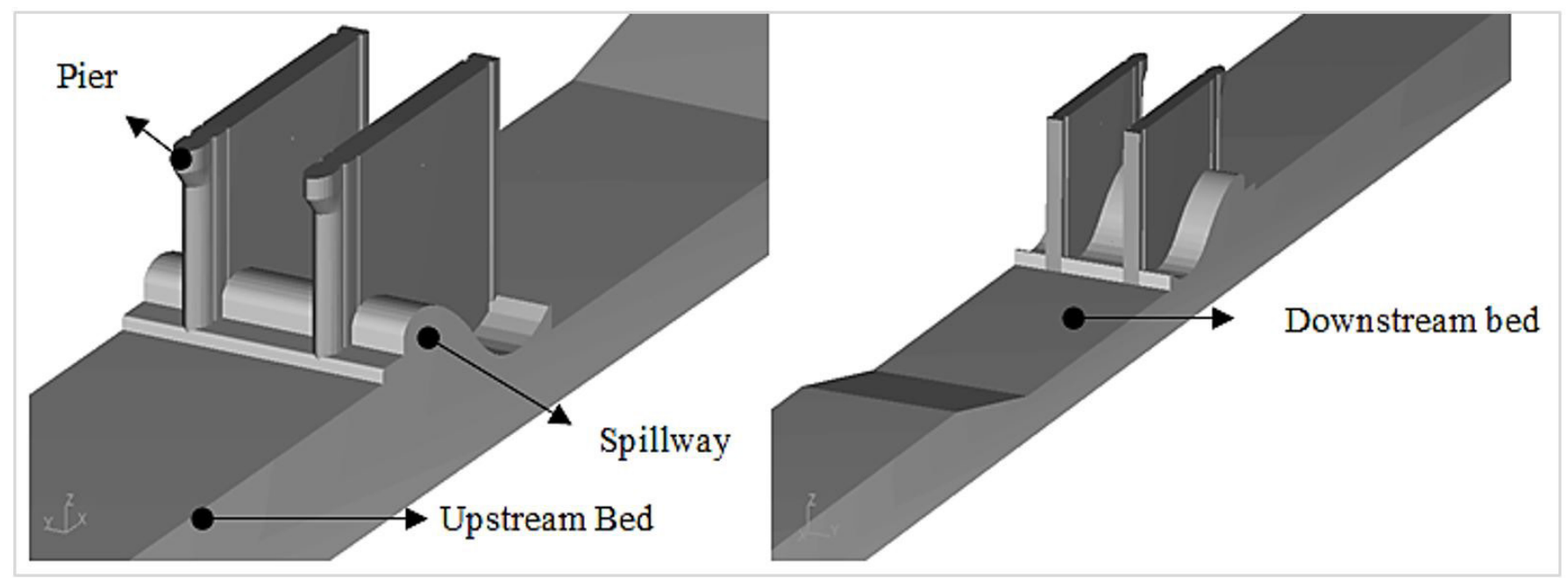

Figure 6. Geometry inserted in model. 


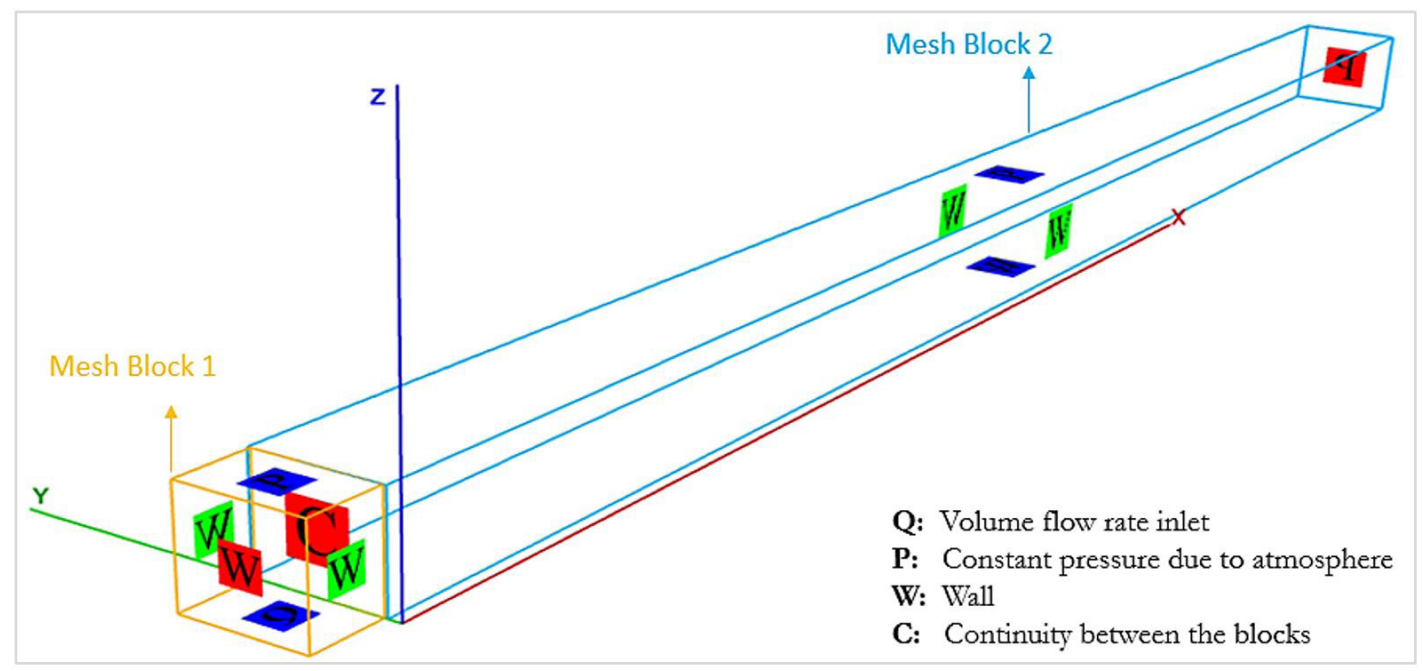

Figure 7. Mesh blocks and boundary conditions used in the computational simulating.
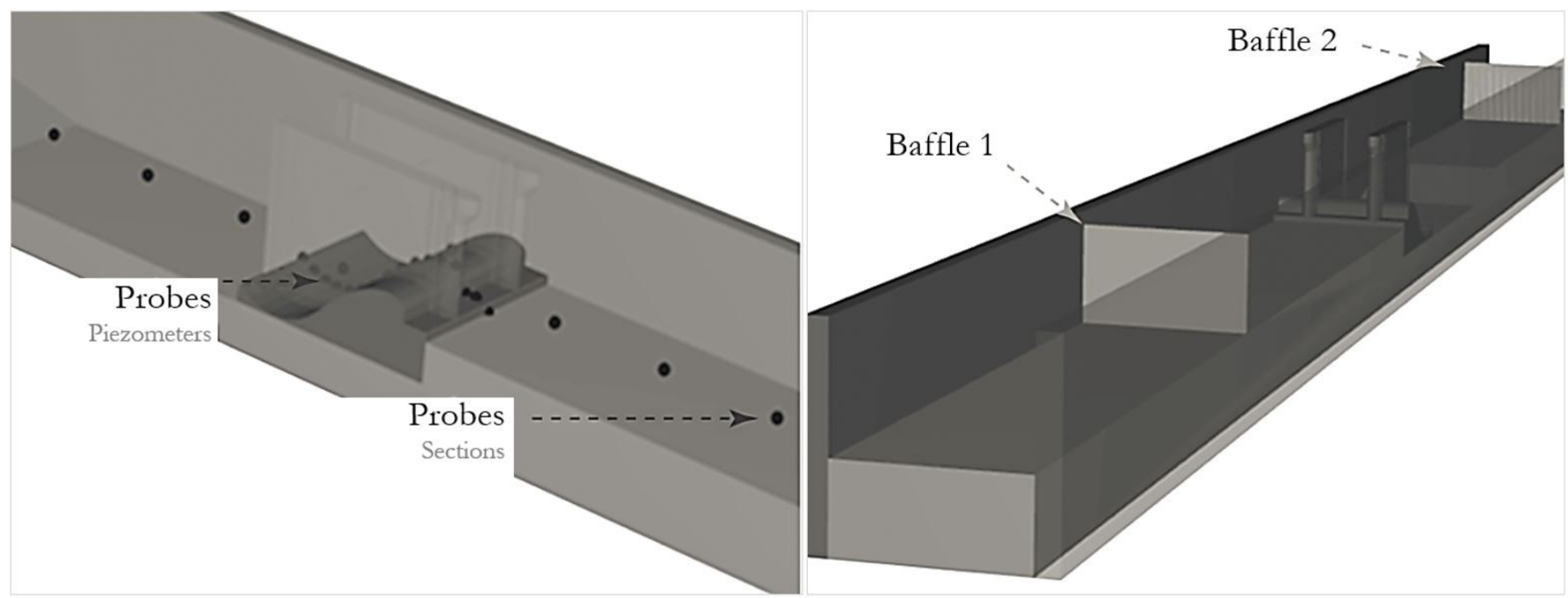

Figure 8. Collection of results from the FLOW-3D ${ }^{\circledR}$ History probe (left) and baffles (right).

\section{RESULTS AND DISCUSSION}

To verify adherence to the continuity law, the results of transit flows were collected after the numerical stabilization of the surface flow. Table 2 demonstrates the results obtained. It is possible to notice the equality between the flow rate imposed as upstream condition and the flow along the channel for all the mesh sizes researched. Therefore, mass conservation and volume properties are guaranteed.

Figure 9 displays height results of the water column for the different computational meshes used and flow rates equal to $0.0160 \mathrm{~m}^{3} / \mathrm{s}$ and $0.177 \mathrm{~m}^{3} / \mathrm{s}$. For both flows it is notable the good adherence among the free surface position along the structure measured in the physical and numerical models, especially for meshes M3 and M4.

For the minimum flow rate, as showed in Table 3, the highest divergence in relation to the average value obtained in the physical model is given in Section E1, passing from the order of $0.012 \mathrm{~m}$ for M1 and M2 and in Section E0, reaching approximately $0.004 \mathrm{~m}$ for meshes M3 and M4.
Regarding to the maximum flow rate, as showed in Table 4, the highest divergence in relation to the average value obtained in the physical model is given in Section E1, passing from the order $0.020 \mathrm{~m}$ for M1 and M2 and in Section E6, reaching approximately $0.012 \mathrm{~m}$ for meshes M3 and M4.

These differences can be considered insignificant, specially the ones detected for meshes M3 and M4, since the water columns obtained from the numerical model are, or inside the range of values measured in the physical model, as the majority of the sections, or so close to them that the difference can be explained by the precision of the physical model instrumentation. It's noteworthy that this great oscillation of the free surface measured in the physical model, particularly in downstream sections, are typical from treating a very turbulent region as occurs in a roller bucket stilling basin.

The pressure loads to the minimum flow rate are shown in Figure 10a. The main deviations observed occurs along the spillway profile (P5 and P6). As demonstrated in Table 5, differences of the order of $65 \%$ ( 0.012 or $12 \mathrm{~mm}$ ) were obtained for the M1 and M2 
Table 2. Resulting flow calculated using Flow-3D ${ }^{\circledR}$ program.

\begin{tabular}{cccccc}
\hline \multirow{2}{*}{ Location } & \multirow{2}{*}{ Physical Model } & \multicolumn{3}{c}{ FLOW-3D $^{\circledR}$} \\
\cline { 2 - 6 } & & M1 & M2 & M3 & M4 \\
\cline { 2 - 6 } Baffle 1 & 0.0160 & 0.0159 & 0.0160 & 0.0160 & 0.0160 \\
Baffle 2 & & 0.0160 & 0.0160 & 0.0160 & 0.0160 \\
Baffle 1 & 0.177 & 0.176 & 0.177 & 0.177 & 0.177 \\
Baffle 2 & & 0.176 & 0.177 & 0.177 & 0.177 \\
\hline
\end{tabular}

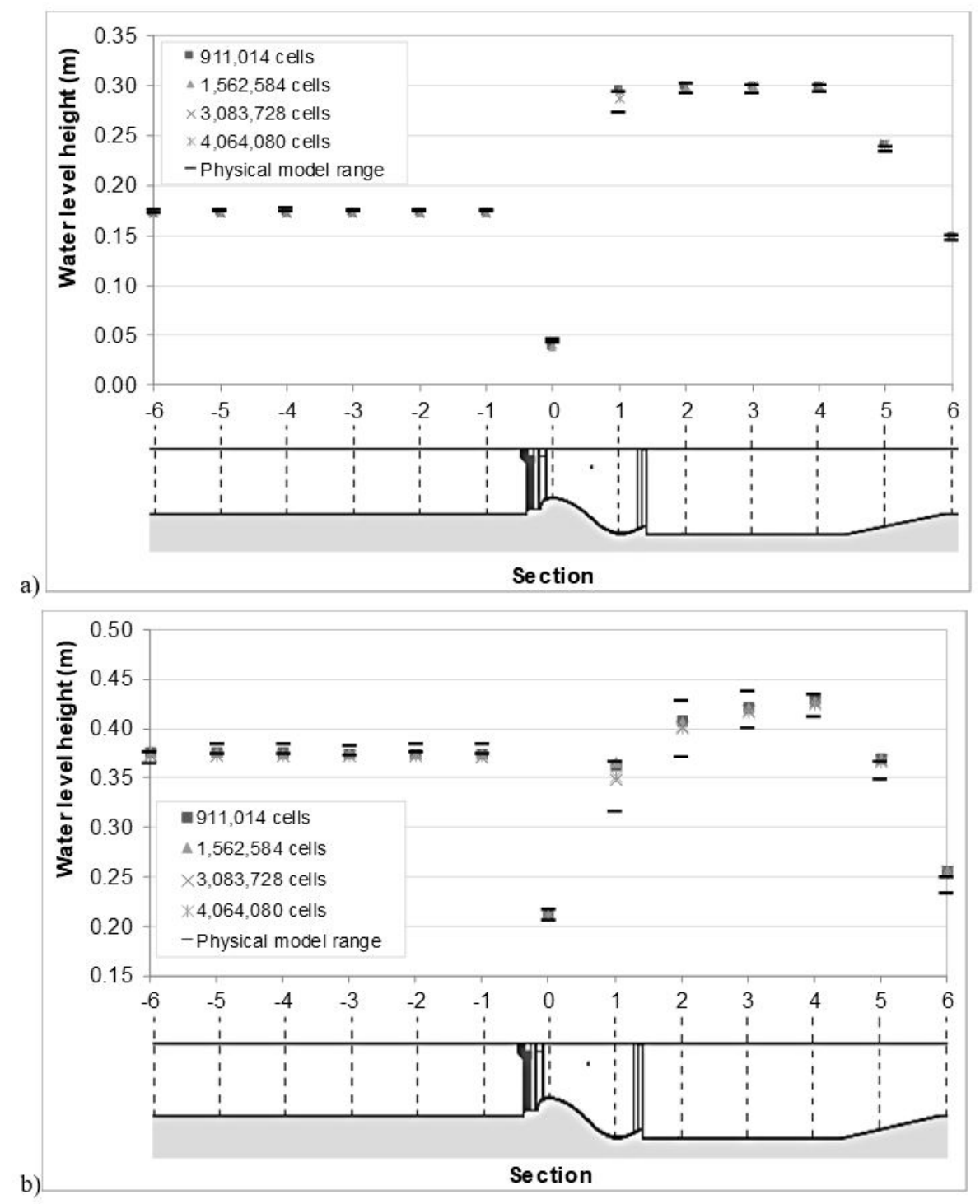

Figure 9. Comparison between experimental and numerical models water surface profile: (a) $\mathrm{Q}=0.016 \mathrm{~m}^{3} / \mathrm{s}$ and $(\mathrm{b}) 0.177 \mathrm{~m}^{3} / \mathrm{s}$.

meshes and were reduced to about $25 \%(0.006$ or $6 \mathrm{~mm})$ for the M3 and M4 meshes. This order of magnitude was also found by authors such as Chanel (2007) and Fill (2011) during the evaluation of the pressure loads on the spillways. It can be considered as acceptable due to the complexity of the flow in this region, influencing the results in both, physical and numerical models.

The maximum flow pressure loads are shown in Figure 10b. The main variation observed occurs in the region of turbulent flow (P9 to P16). As demonstrated in Table 6, differences of the order of $0.06 \mathrm{~m}$ or $60.0 \mathrm{~mm}$ were obtained for the all meshes and can be considered acceptable since even using piezometers, which have the characteristic of attenuate pressure oscillations, pressure loads measured in this region of the physical model variated significantly.

Outside this region, especially in the spillway crest, differences can be also assigned to the ability of the method itself to represent the curved geometry based on facets. However, the general behavior can be considered satisfactory for the analyzed flow, by presenting the same trend in relation to the hydraulic line. For example, in the region of the crest of the spillway the 
Table 3. Water column results obtained using Flow- $3 \mathrm{D}^{\circledR}$ program $-\mathrm{Q}=0.016 \mathrm{~m} 3 \mathrm{~s}$.

\begin{tabular}{|c|c|c|c|c|c|c|c|c|c|c|}
\hline \multirow[b]{3}{*}{ Section } & \multirow{2}{*}{\multicolumn{2}{|c|}{ Physical model }} & \multicolumn{8}{|c|}{ FLOW-3D ${ }^{\circledR}$} \\
\hline & & & \multicolumn{2}{|c|}{ M1 } & \multicolumn{2}{|c|}{ M2 } & \multicolumn{2}{|c|}{ M3 } & \multicolumn{2}{|c|}{ M4 } \\
\hline & $\begin{array}{l}\text { Minimum } \\
\text { water } \\
\text { column } \\
\text { (m) }\end{array}$ & $\begin{array}{l}\text { Maximum } \\
\text { water } \\
\text { column } \\
\text { (m) }\end{array}$ & $\begin{array}{l}\text { Water } \\
\text { column } \\
\text { (m) }\end{array}$ & $\begin{array}{l}\text { Absolute } \\
\text { difference } \\
\text { (m) }\end{array}$ & $\begin{array}{l}\text { Water } \\
\text { column } \\
\text { (m) }\end{array}$ & $\begin{array}{l}\text { Absolute } \\
\text { difference } \\
\text { (m) }\end{array}$ & $\begin{array}{l}\text { Water } \\
\text { column } \\
\text { (m) }\end{array}$ & $\begin{array}{l}\text { Absolute } \\
\text { difference } \\
\text { (m) }\end{array}$ & $\begin{array}{l}\text { Water } \\
\text { column } \\
\text { (m) }\end{array}$ & $\begin{array}{c}\text { Absolute } \\
\text { difference } \\
\text { (m) }\end{array}$ \\
\hline-6 & 0.1735 & 0.1765 & 0.1729 & -0.0021 & 0.1729 & -0.0021 & 0.1728 & -0.0022 & 0.1741 & -0.0009 \\
\hline-5 & 0.1738 & 0.1768 & 0.1728 & -0.0025 & 0.1729 & -0.0024 & 0.1728 & -0.0025 & 0.1741 & -0.0012 \\
\hline-4 & 0.1743 & 0.1772 & 0.1728 & -0.0030 & 0.1729 & -0.0029 & 0.1728 & -0.0030 & 0.1741 & -0.0017 \\
\hline-3 & 0.1738 & 0.1768 & 0.1728 & -0.0025 & 0.1729 & -0.0024 & 0.1728 & -0.0025 & 0.1741 & -0.0012 \\
\hline-2 & 0.1742 & 0.1770 & 0.1728 & -0.0028 & 0.1729 & -0.0027 & 0.1728 & -0.0028 & 0.1741 & -0.0015 \\
\hline-1 & 0.1738 & 0.1767 & 0.1728 & -0.0025 & 0.1729 & -0.0024 & 0.1728 & -0.0025 & 0.1741 & -0.0012 \\
\hline 0 & 0.0432 & 0.0463 & 0.0371 & -0.0077 & 0.0372 & -0.0076 & 0.0408 & -0.0040 & 0.0405 & -0.0043 \\
\hline 1 & 0.2730 & 0.2942 & 0.2956 & 0.0120 & 0.2945 & 0.0109 & 0.2871 & 0.0035 & 0.2866 & 0.0030 \\
\hline 2 & 0.2930 & 0.3025 & 0.2979 & 0.0001 & 0.2968 & -0.0010 & 0.2995 & 0.0017 & 0.2992 & 0.0014 \\
\hline 3 & 0.2935 & 0.3012 & 0.2984 & 0.0011 & 0.2985 & 0.0012 & 0.2994 & 0.0021 & 0.2992 & 0.0019 \\
\hline 4 & 0.2950 & 0.3010 & 0.2988 & 0.0008 & 0.2992 & 0.0012 & 0.2994 & 0.0014 & 0.2994 & 0.0014 \\
\hline 5 & 0.2352 & 0.2395 & 0.2409 & 0.0036 & 0.2411 & 0.0038 & 0.2411 & 0.0038 & 0.2404 & 0.0031 \\
\hline 6 & 0.1458 & 0.1498 & 0.1485 & 0.0007 & 0.1486 & 0.0008 & 0.1486 & 0.0008 & 0.1486 & 0.0008 \\
\hline
\end{tabular}

a)
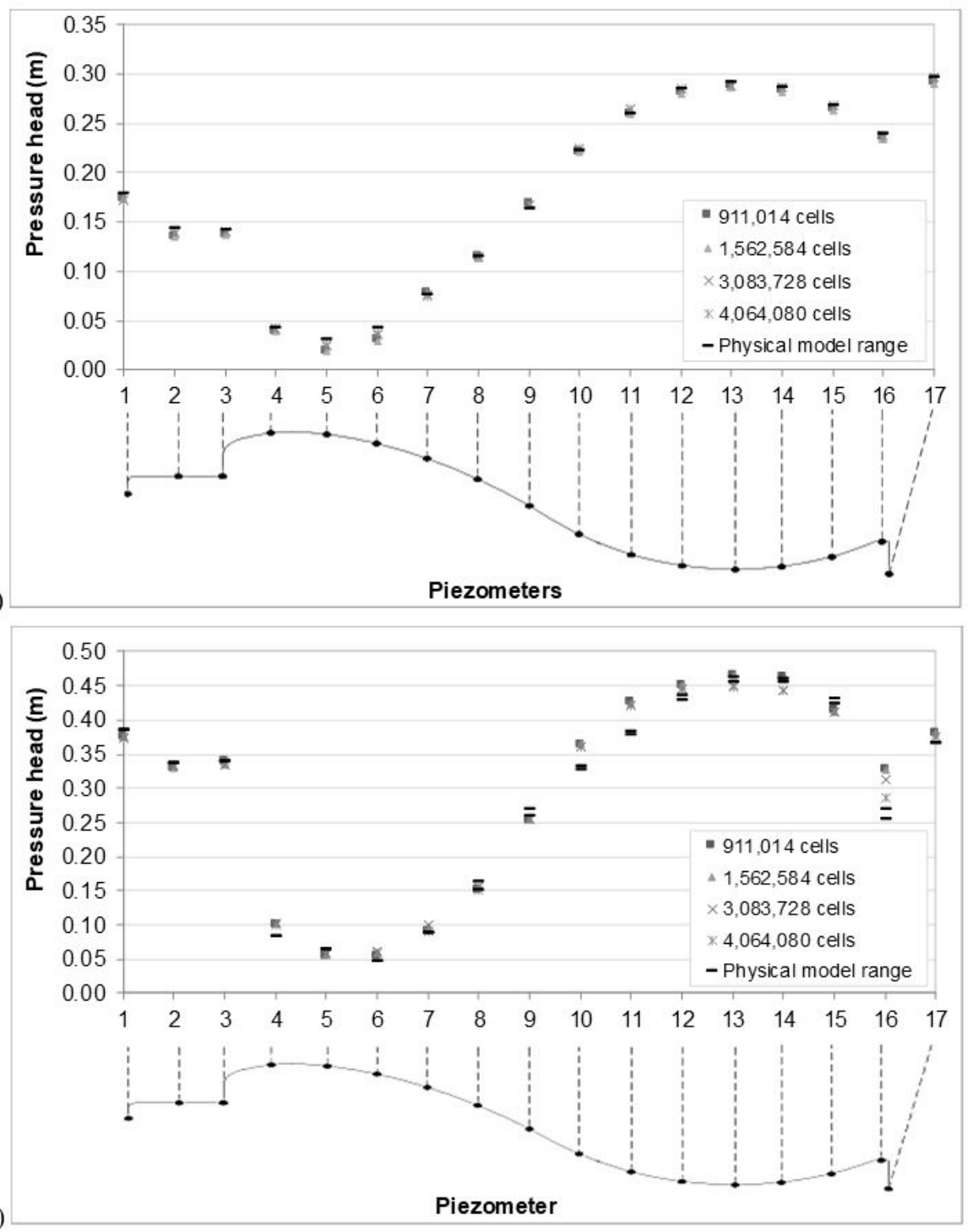

Figure 10. Comparison between experimental and numerical models pressure head: (a) $\mathrm{Q}=0.016 \mathrm{~m}^{3} / \mathrm{s}$ and $(\mathrm{b}) \mathrm{Q}=0.177 \mathrm{~m}^{3} / \mathrm{s}$. 
Table 4. Water column results obtained using Flow- $3 \mathrm{D}^{\circledR}$ program $-\mathrm{Q}=0.177 \mathrm{~m}^{3} / \mathrm{s}$.

\begin{tabular}{|c|c|c|c|c|c|c|c|c|c|c|}
\hline \multirow[b]{3}{*}{ Section } & \multirow{2}{*}{\multicolumn{2}{|c|}{ Physical model }} & \multicolumn{8}{|c|}{ FLOW-3D ${ }^{\circledR}$} \\
\hline & & & \multicolumn{2}{|c|}{ M1 } & \multicolumn{2}{|c|}{ M2 } & \multicolumn{2}{|c|}{ M3 } & \multicolumn{2}{|c|}{ M4 } \\
\hline & $\begin{array}{l}\text { Minimum } \\
\text { water } \\
\text { column } \\
(\mathrm{m})\end{array}$ & $\begin{array}{l}\text { Maximum } \\
\text { water } \\
\text { column } \\
(\mathrm{m})\end{array}$ & $\begin{array}{l}\text { Water } \\
\text { column } \\
\text { (m) }\end{array}$ & $\begin{array}{l}\text { Absolute } \\
\text { difference } \\
\text { (m) }\end{array}$ & $\begin{array}{l}\text { Water } \\
\text { column } \\
(\mathrm{m})\end{array}$ & $\begin{array}{l}\text { Absolute } \\
\text { difference } \\
\text { (m) }\end{array}$ & $\begin{array}{l}\text { Water } \\
\text { column } \\
\text { (m) }\end{array}$ & $\begin{array}{l}\text { Absolute } \\
\text { difference } \\
\text { (m) }\end{array}$ & $\begin{array}{c}\text { Water } \\
\text { column } \\
(\mathrm{m})\end{array}$ & $\begin{array}{l}\text { Absolute } \\
\text { difference } \\
\text { (m) }\end{array}$ \\
\hline-6 & 0.3652 & 0.3763 & 0.3749 & 0.0042 & 0.3747 & 0.0040 & 0.3721 & 0.0014 & 0.3725 & 0.0018 \\
\hline-5 & 0.3736 & 0.3841 & 0.3746 & -0.0043 & 0.3744 & -0.0045 & 0.3719 & -0.0070 & 0.3723 & -0.0066 \\
\hline-4 & 0.3733 & 0.3838 & 0.3743 & -0.0042 & 0.3740 & -0.0045 & 0.3717 & -0.0068 & 0.3720 & -0.0065 \\
\hline-3 & 0.3725 & 0.3829 & 0.3740 & -0.0037 & 0.3737 & -0.0040 & 0.3715 & -0.0062 & 0.3718 & -0.0059 \\
\hline-2 & 0.3751 & 0.3845 & 0.3737 & -0.0061 & 0.3734 & -0.0064 & 0.3712 & -0.0086 & 0.3716 & -0.0082 \\
\hline-1 & 0.3736 & 0.3837 & 0.3731 & -0.0056 & 0.3728 & -0.0059 & 0.3707 & -0.0080 & 0.3711 & -0.0076 \\
\hline 0 & 0.2059 & 0.2167 & 0.2112 & -0.0001 & 0.2109 & -0.0004 & 0.2108 & -0.0005 & 0.2104 & -0.0009 \\
\hline 1 & 0.3156 & 0.3660 & 0.3615 & 0.0207 & 0.3645 & 0.0237 & 0.3473 & 0.0065 & 0.3510 & 0.0062 \\
\hline 2 & 0.3704 & 0.4268 & 0.4073 & 0.0087 & 0.4061 & 0.0075 & 0.4012 & 0.0026 & 0.3999 & 0.0013 \\
\hline 3 & 0.4003 & 0.4371 & 0.4209 & 0.0022 & 0.4200 & 0.0013 & 0.4177 & -0.0010 & 0.4152 & -0.0035 \\
\hline 4 & 0.4110 & 0.4342 & 0.4278 & 0.0052 & 0.4272 & 0.0046 & 0.4255 & 0.0029 & 0.4233 & 0.0007 \\
\hline 5 & 0.3482 & 0.3665 & 0.3683 & 0.0110 & 0.3679 & 0.0106 & 0.3664 & 0.0091 & 0.3647 & 0.0074 \\
\hline 6 & 0.2333 & 0.2500 & 0.2554 & 0.0137 & 0.2552 & 0.0135 & 0.2544 & 0.0127 & 0.2533 & 0.0116 \\
\hline
\end{tabular}

Table 5. Pressure load results obtained using Flow $-3 \mathrm{D}^{\circledR}$ program $-\mathrm{Q}=0.016 \mathrm{~m}^{3} / \mathrm{s}$.

\begin{tabular}{|c|c|c|c|c|c|c|c|c|c|}
\hline \multirow[b]{3}{*}{ Section } & \multirow{3}{*}{ 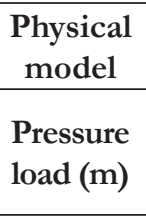 } & \multicolumn{8}{|c|}{ FLOW-3D ${ }^{\circledR}$} \\
\hline & & \multicolumn{2}{|c|}{ M1 } & \multicolumn{2}{|c|}{ M2 } & \multicolumn{2}{|c|}{ M3 } & \multicolumn{2}{|c|}{ M4 } \\
\hline & & $\begin{array}{l}\text { Pressure } \\
\text { load (m) }\end{array}$ & $\begin{array}{c}\text { Absolute } \\
\text { difference } \\
\text { (m) }\end{array}$ & $\begin{array}{l}\text { Pressure } \\
\text { load (m) }\end{array}$ & $\begin{array}{c}\text { Absolute } \\
\text { difference }(\mathrm{m})\end{array}$ & $\begin{array}{l}\text { Pressure } \\
\text { load (m) }\end{array}$ & $\begin{array}{c}\text { Absolute } \\
\text { difference }(\mathrm{m})\end{array}$ & $\begin{array}{l}\text { Pressure } \\
\text { load (m) }\end{array}$ & $\begin{array}{c}\text { Absolute } \\
\text { difference(m) }\end{array}$ \\
\hline 1 & 0.1780 & 0.1730 & -0.0050 & 0.1731 & -0.0049 & 0.1713 & -0.0067 & 0.1726 & -0.0054 \\
\hline 2 & 0.1430 & 0.1357 & -0.0073 & 0.1357 & -0.0073 & 0.1390 & -0.0040 & 0.1404 & -0.0026 \\
\hline 3 & 0.1420 & 0.1362 & -0.0058 & 0.1363 & -0.0057 & 0.1392 & -0.0028 & 0.1407 & -0.0013 \\
\hline 4 & 0.0420 & 0.0396 & -0.0024 & 0.0397 & -0.0023 & 0.0414 & -0.0006 & 0.0425 & 0.0005 \\
\hline 5 & 0.0310 & 0.0188 & -0.0122 & 0.0187 & -0.0123 & 0.0242 & -0.0068 & 0.0252 & -0.0058 \\
\hline 6 & 0.0430 & 0.0308 & -0.0122 & 0.0298 & -0.0132 & 0.0364 & -0.0066 & 0.0370 & -0.0060 \\
\hline 7 & 0.0760 & 0.0784 & 0.0024 & 0.0773 & 0.0013 & 0.0760 & 0.0000 & 0.0744 & -0.0016 \\
\hline 8 & 0.1140 & 0.1148 & 0.0008 & 0.1137 & -0.0003 & 0.1151 & 0.0011 & 0.1146 & 0.0006 \\
\hline 9 & 0.1640 & 0.1678 & 0.0038 & 0.1667 & 0.0027 & 0.1669 & 0.0029 & 0.1669 & 0.0029 \\
\hline 10 & 0.2230 & 0.2212 & -0.0018 & 0.2202 & -0.0028 & 0.2239 & 0.0009 & 0.2236 & 0.0006 \\
\hline 11 & 0.2590 & 0.2599 & 0.0009 & 0.2589 & -0.0001 & 0.2643 & 0.0053 & 0.2645 & 0.0055 \\
\hline 12 & 0.2840 & 0.2807 & -0.0033 & 0.2797 & -0.0043 & 0.2851 & 0.0011 & 0.2850 & 0.0010 \\
\hline 13 & 0.2920 & 0.2876 & -0.0044 & 0.2867 & -0.0053 & 0.2887 & -0.0033 & 0.2882 & -0.0038 \\
\hline 14 & 0.2870 & 0.2826 & -0.0044 & 0.2814 & -0.0056 & 0.2868 & -0.0002 & 0.2864 & -0.0006 \\
\hline 15 & 0.2670 & 0.2640 & -0.0030 & 0.2629 & -0.0041 & 0.2682 & 0.0012 & 0.2677 & 0.0007 \\
\hline 16 & 0.2400 & 0.2357 & -0.0043 & 0.2348 & -0.0052 & 0.2372 & -0.0028 & 0.2347 & -0.0053 \\
\hline 17 & 0.2970 & 0.2910 & -0.0060 & 0.2903 & -0.0067 & 0.2969 & -0.0001 & 0.2966 & -0.0004 \\
\hline
\end{tabular}

hydraulic line showing a decrease in the values of the pressure loads is observed. This is expected because this is a region of acceleration of the surface flow, i.e., there is an increase of velocity and consequently greater contribution of kinetic energy to the total energy of the surface flow. The same behavior could be observed by Araujo Filho \& Ota (2016).

Regarding the velocities obtained, in Figure 11a it is observed that the vertical profiles of velocity to the minimum flow rate obtained for M1 and M2 meshes presented a pattern that is inconsistent with the one observed in the physical model, particularly, in the superficial layers of the surface flow, where the flow direction is reversed. For M3 and M4 meshes, the velocities have been presented within the validity limits of the physical model because the rollers formed in the dissipator induce negative surface flow velocities (from downstream to upstream). Regarding to the velocities to maximum flow rate (Figure 11b) it is observed a similar behavior in both models, however it is possible to observe that the velocities obtained in the surface layers of the flow are slightly larger in the numerical model, regardless to the mesh used. The observed difference can be attributed to the experimental method used to measure velocities as well as turbulent flow.

Figure 12 illustrates the flow pattern in the physical model for the minimum flow where it is possible to observe, with the aid of dye, the main currents and recirculating regions. It also shows that there is an adhesion of the liquid fillets next to the profile and dissipating bucket. To conduct a comparative analysis, Figure 13 
Table 6. Pressure load results obtained using Flow-3D ${ }^{\circledR}$ program $-\mathrm{Q}=0.177 \mathrm{~m}^{3} / \mathrm{s}$.

\begin{tabular}{|c|c|c|c|c|c|c|c|c|c|c|}
\hline \multirow[b]{3}{*}{ Section } & \multirow{2}{*}{\multicolumn{2}{|c|}{ Physical model }} & \multicolumn{8}{|c|}{ FLOW-3D ${ }^{\circledR}$} \\
\hline & & & \multicolumn{2}{|c|}{ M1 } & \multicolumn{2}{|c|}{ M2 } & \multicolumn{2}{|c|}{ M3 } & \multicolumn{2}{|c|}{ M4 } \\
\hline & $\begin{array}{l}\text { Minimum } \\
\text { pressure } \\
\text { load }(\mathrm{m})\end{array}$ & $\begin{array}{c}\text { Maximum } \\
\text { pressure } \\
\text { load (m) }\end{array}$ & $\begin{array}{l}\text { Pressure } \\
\text { load (m) }\end{array}$ & $\begin{array}{c}\text { Absolute } \\
\text { difference } \\
(\mathrm{m})\end{array}$ & $\begin{array}{l}\text { Pressure } \\
\text { load (m) }\end{array}$ & $\begin{array}{c}\text { Absolute } \\
\text { difference } \\
(\mathrm{m})\end{array}$ & $\begin{array}{l}\text { Pressure } \\
\text { load (m) }\end{array}$ & $\begin{array}{c}\text { Absolute } \\
\text { difference } \\
(\mathrm{m})\end{array}$ & $\begin{array}{l}\text { Pressure } \\
\text { load (m) }\end{array}$ & $\begin{array}{c}\text { Absolute } \\
\text { difference } \\
(\mathrm{m})\end{array}$ \\
\hline 1 & \multicolumn{2}{|c|}{0.3840} & 0.3760 & -0.0080 & 0.3753 & -0.0087 & 0.3735 & -0.0105 & 0.3745 & -0.0095 \\
\hline 2 & \multicolumn{2}{|c|}{0.3360} & 0.3301 & -0.0059 & 0.3292 & -0.0068 & 0.3328 & -0.0032 & 0.3351 & -0.0009 \\
\hline 3 & \multicolumn{2}{|c|}{0.3400} & 0.3382 & -0.0018 & 0.3355 & -0.0045 & 0.3353 & -0.0047 & 0.3381 & -0.0019 \\
\hline 4 & \multicolumn{2}{|c|}{0.0820} & 0.1009 & 0.0189 & 0.1020 & 0.0200 & 0.1032 & 0.0212 & 0.0989 & 0.0169 \\
\hline 5 & \multicolumn{2}{|c|}{0.0630} & 0.0536 & -0.0094 & 0.0563 & -0.0067 & 0.0582 & -0.0048 & 0.0554 & -0.0076 \\
\hline 6 & \multicolumn{2}{|c|}{0.0470} & 0.0551 & 0.0081 & 0.0582 & 0.0112 & 0.0625 & 0.0155 & 0.0597 & 0.0127 \\
\hline 7 & \multicolumn{2}{|c|}{0.0870} & 0.0911 & 0.0041 & 0.0951 & 0.0081 & 0.1005 & 0.0135 & 0.0914 & 0.0044 \\
\hline 8 & 0.1630 & 0.1510 & 0.1506 & -0.0064 & 0.1557 & -0.0013 & 0.1556 & -0.0014 & 0.1511 & -0.0059 \\
\hline 9 & 0.2680 & 0.3600 & 0.2511 & -0.0629 & 0.2554 & -0.0586 & 0.2535 & -0.0605 & 0.2543 & -0.0597 \\
\hline 10 & 0.3310 & 0.3270 & 0.3641 & 0.0351 & 0.3652 & 0.0362 & 0.3617 & 0.0327 & 0.3603 & 0.0313 \\
\hline 11 & 0.3830 & 0.3770 & 0.4255 & 0.0455 & 0.4250 & 0.0450 & 0.4224 & 0.0424 & 0.4225 & 0.0425 \\
\hline 12 & 0.4360 & 0.4280 & 0.4501 & 0.0181 & 0.4497 & 0.0177 & 0.4466 & 0.0146 & 0.4460 & 0.0140 \\
\hline 13 & 0.4620 & 0.4560 & 0.4647 & 0.0057 & 0.4640 & 0.0050 & 0.4493 & -0.0097 & 0.4484 & -0.0106 \\
\hline 14 & 0.4610 & 0.4550 & 0.4614 & 0.0034 & 0.4599 & 0.0019 & 0.4429 & -0.0151 & 0.4430 & -0.0150 \\
\hline 15 & 0.4300 & 0.4240 & 0.4142 & -0.0128 & 0.4125 & -0.0145 & 0.4121 & -0.0149 & 0.4127 & -0.0143 \\
\hline 16 & 0.2700 & 0.2540 & 0.3268 & 0.0648 & 0.3260 & 0.0640 & 0.3129 & 0.0509 & 0.2851 & 0.0231 \\
\hline 17 & 0.3650 & 0.3650 & 0.3800 & 0.0150 & 0.3810 & 0.0160 & 0.3754 & 0.0104 & 0.3748 & 0.0098 \\
\hline
\end{tabular}

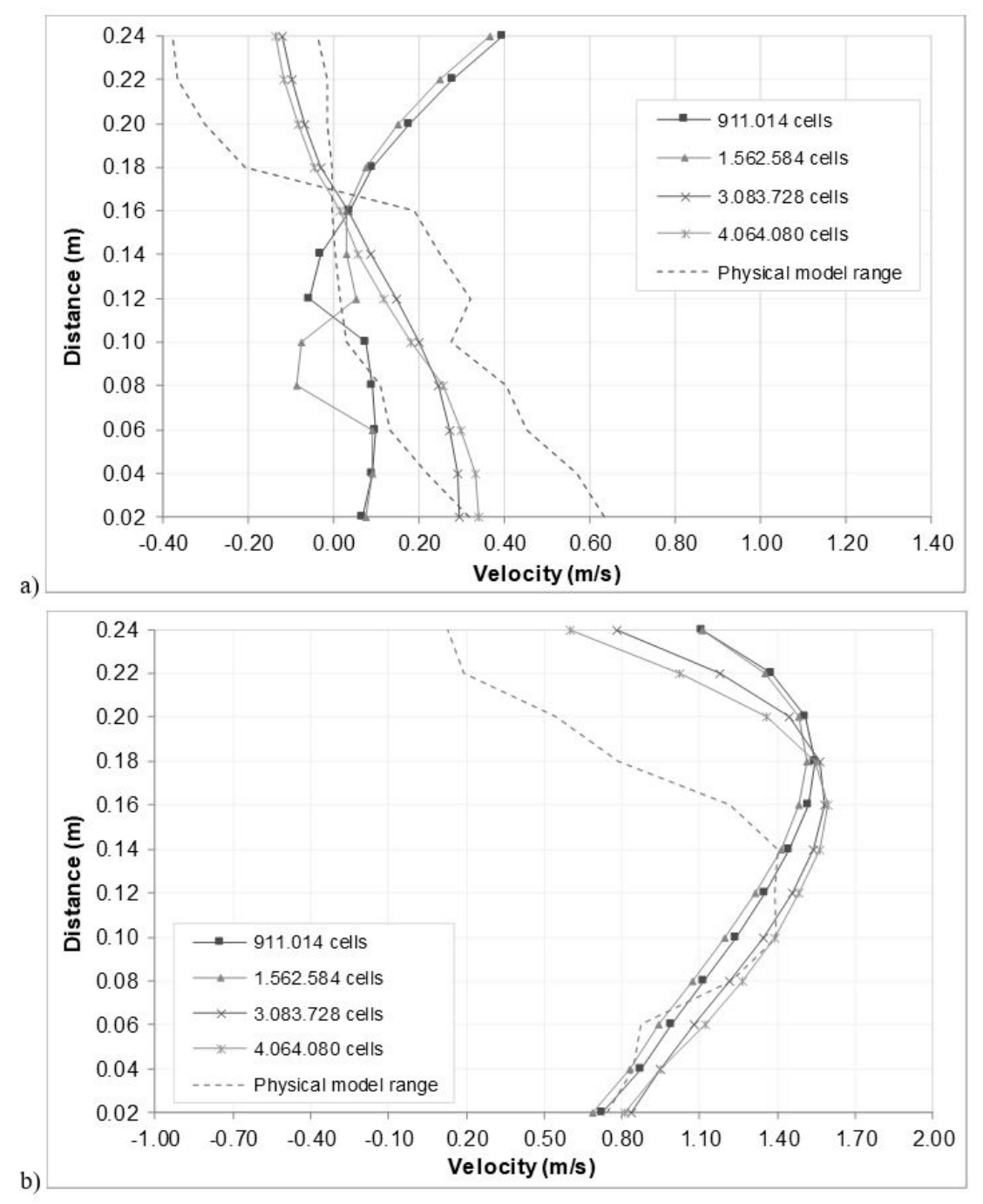

Figure 11. Vertical profile of velocity: (a) $Q=0.016 \mathrm{~m}^{3} / \mathrm{s}$ and (b) $\mathrm{Q}=0.177 \mathrm{~m}^{3} / \mathrm{s}$. 

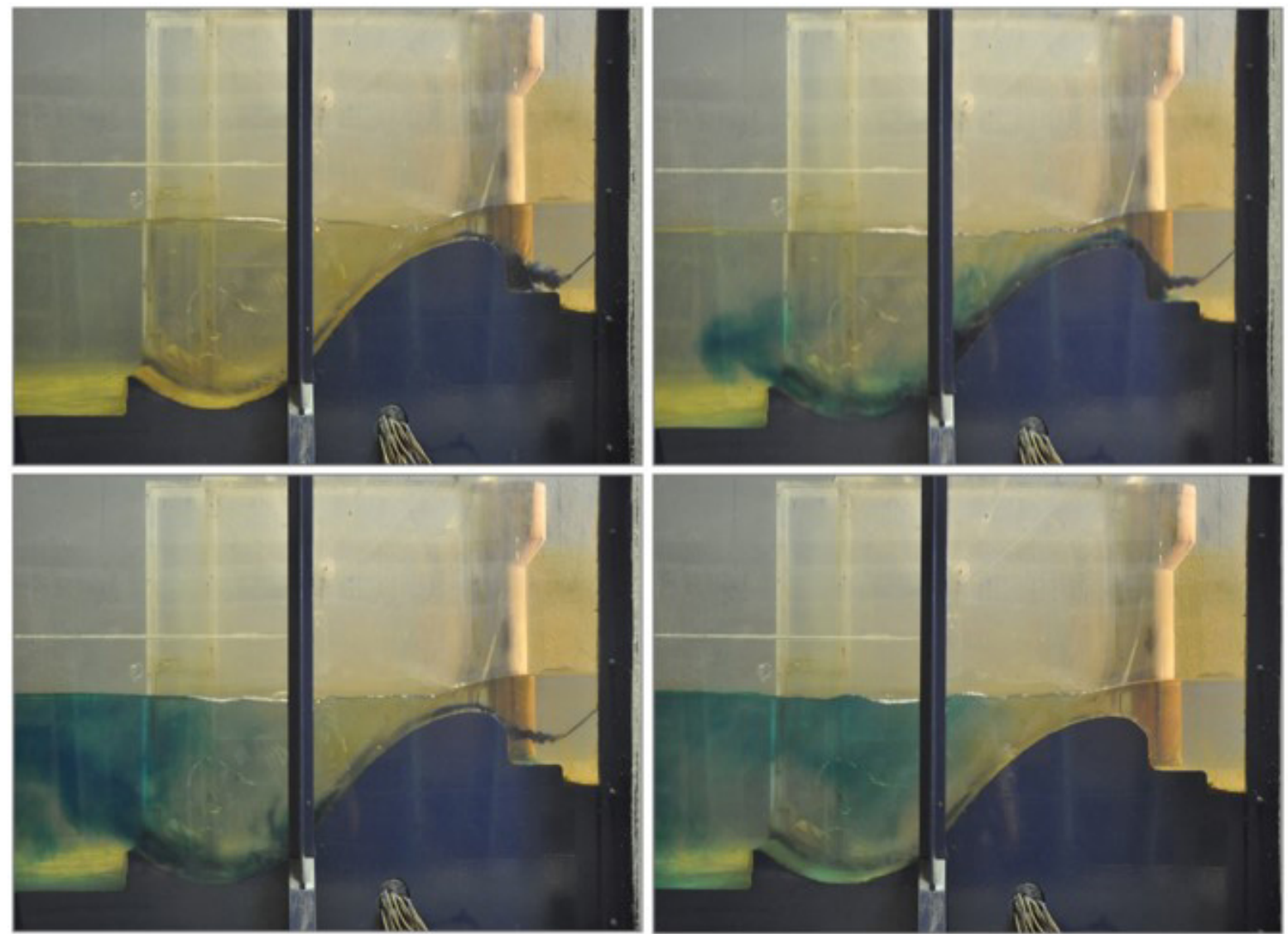

Figure 12. Flow pattern in the physical model evidenced by dye addition $-\mathrm{Q}=0.016 \mathrm{~m}^{3} / \mathrm{s}$.

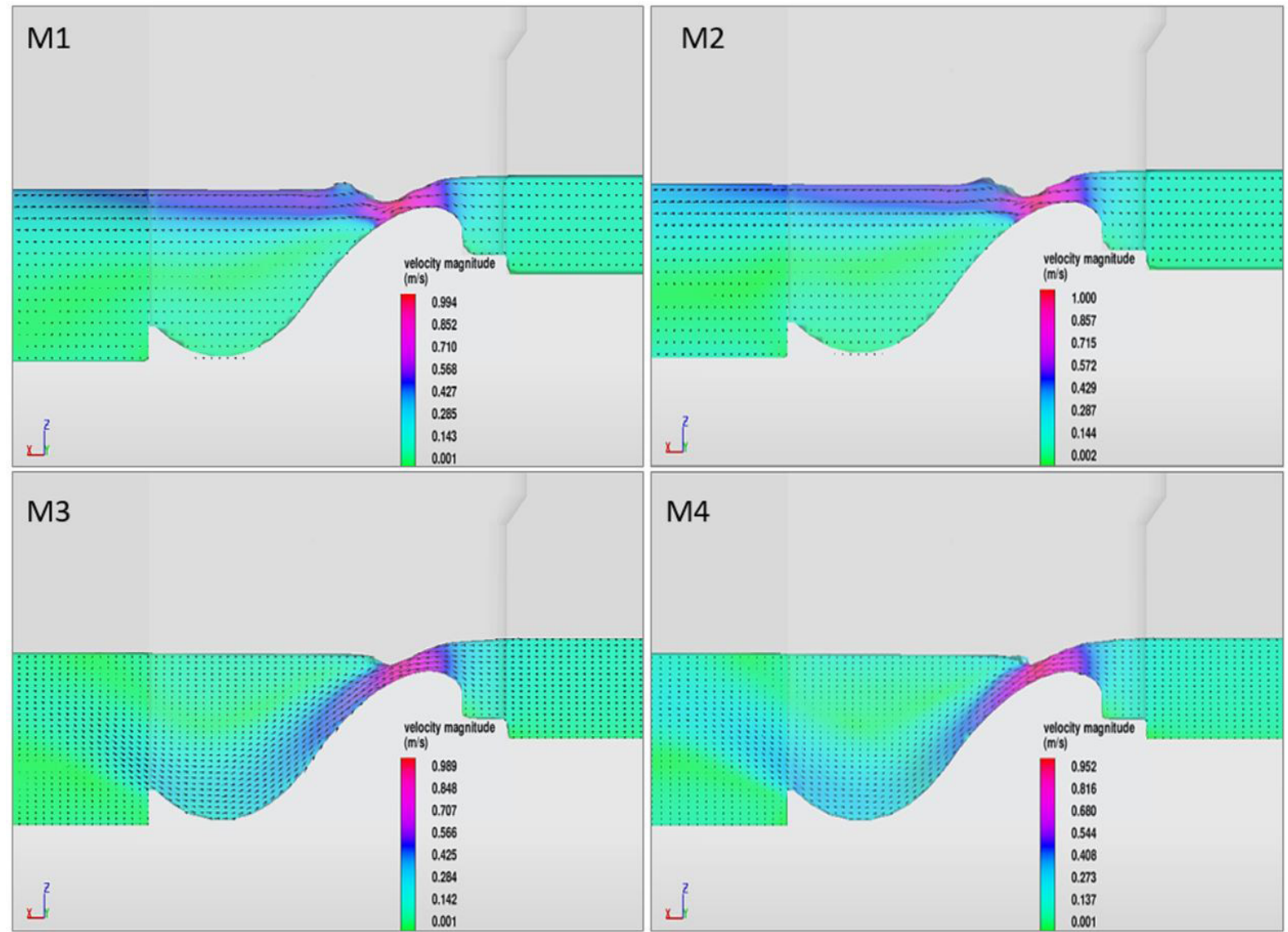

Figure 13. Pattern of flow in numerical model $-\mathrm{Q}=0.016 \mathrm{~m}^{3} / \mathrm{s}$. 
presents, for the instant of time characterized by permanent flow, the surface flow pattern obtained in FLOW-3D ${ }^{\circledR}$ program for the different meshes. It observed that for M1 and M2 meshes, the main flow tends to run downstream through the shallow layers of the surface flow. For M3 and M4 meshes, there is the adhesion of the flow to the bottom, as observed in the physical model. In Figure 14 the tendency of formation of dissipating rollers can be observed just above the bucket and immediately downstream of the structure bucket with sill.
Figure 15 illustrates the flow pattern in the physical model to the maximum flow rate where it is possible to observe, with the aid of dye, the main currents and recirculating regions. To conduct a comparative analysis, Figure 16 presents, for the instant of time characterized by permanent flow, the surface flow pattern obtained in FLOW-3D ${ }^{\circledR}$ program for the different meshes where no significant differences were identified between the meshes used. In Figure 17 it can be observed the tendency of formation of dissipating rollers as in physical model.
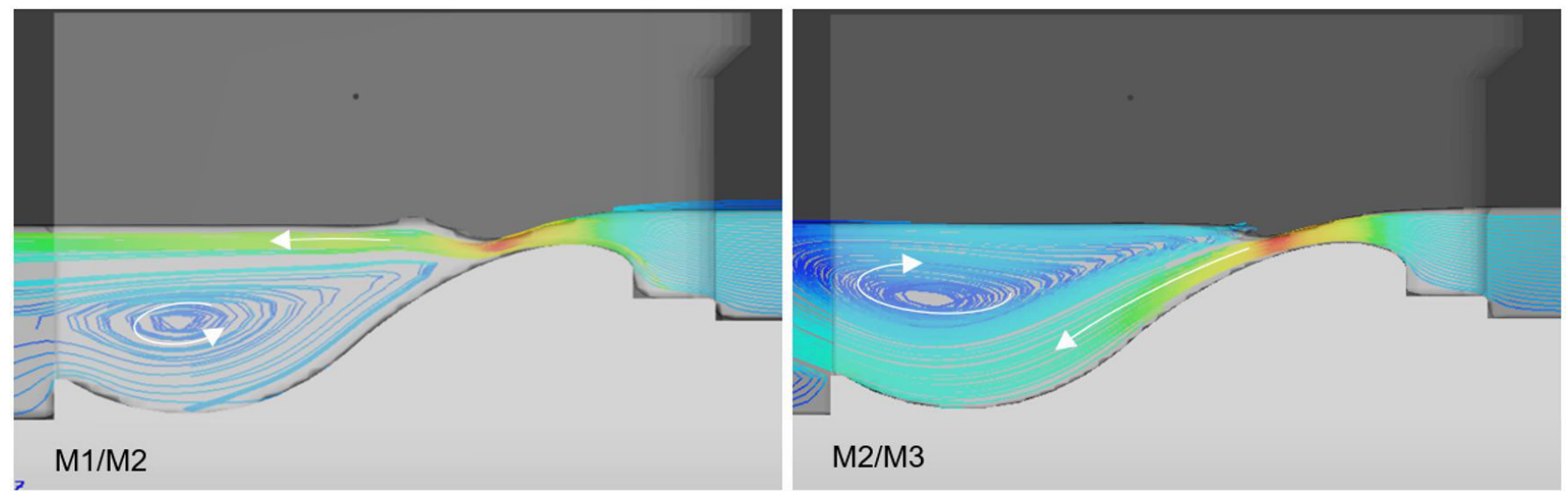

Figure 14. Stream lines in numerical model $-\mathrm{Q}=0.016 \mathrm{~m}^{3} / \mathrm{s}$.
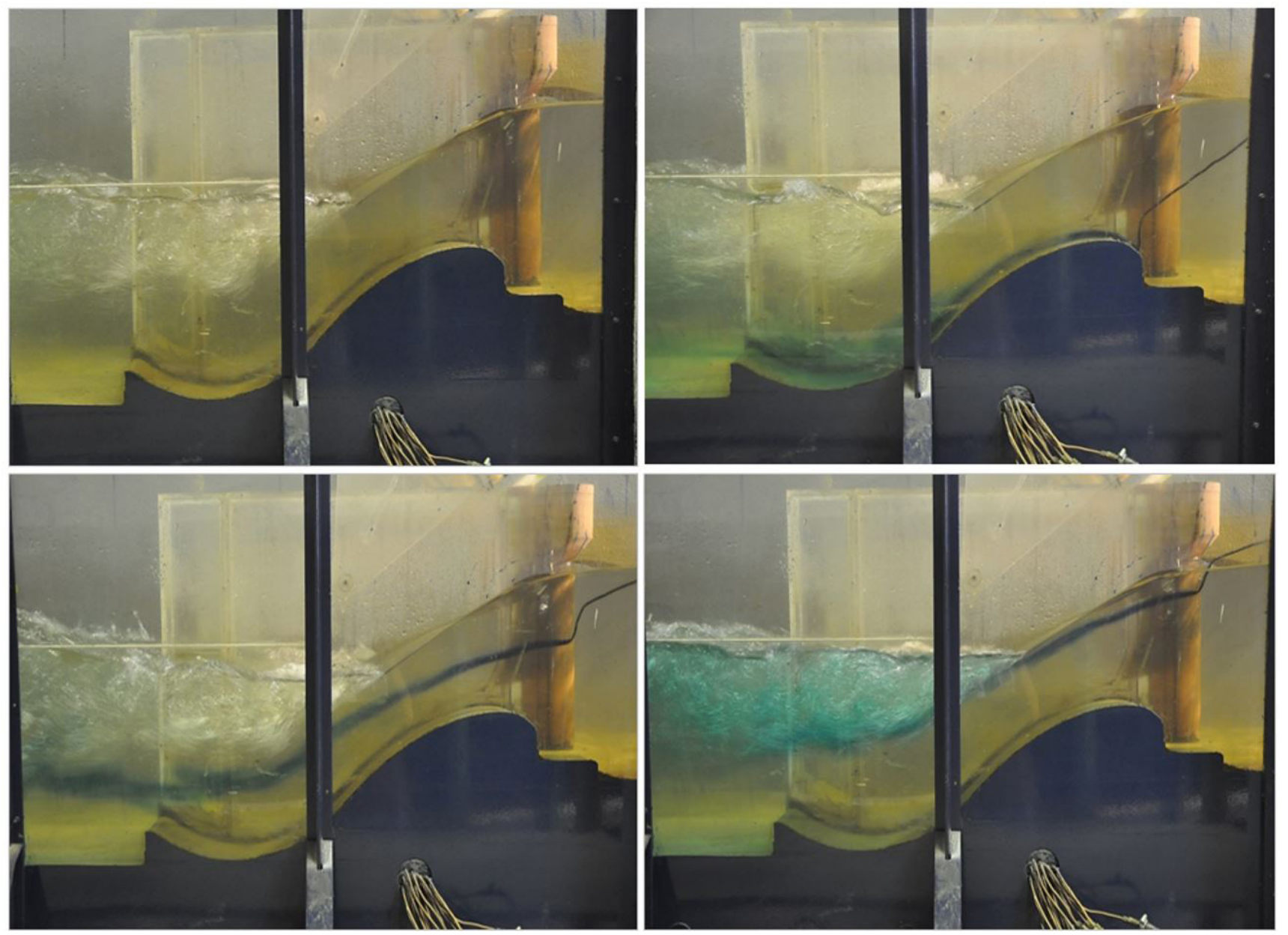

Figure 15. Flow pattern in the physical model evidenced by dye addition $-\mathrm{Q}=0.177 \mathrm{~m}^{3} / \mathrm{s}$. 

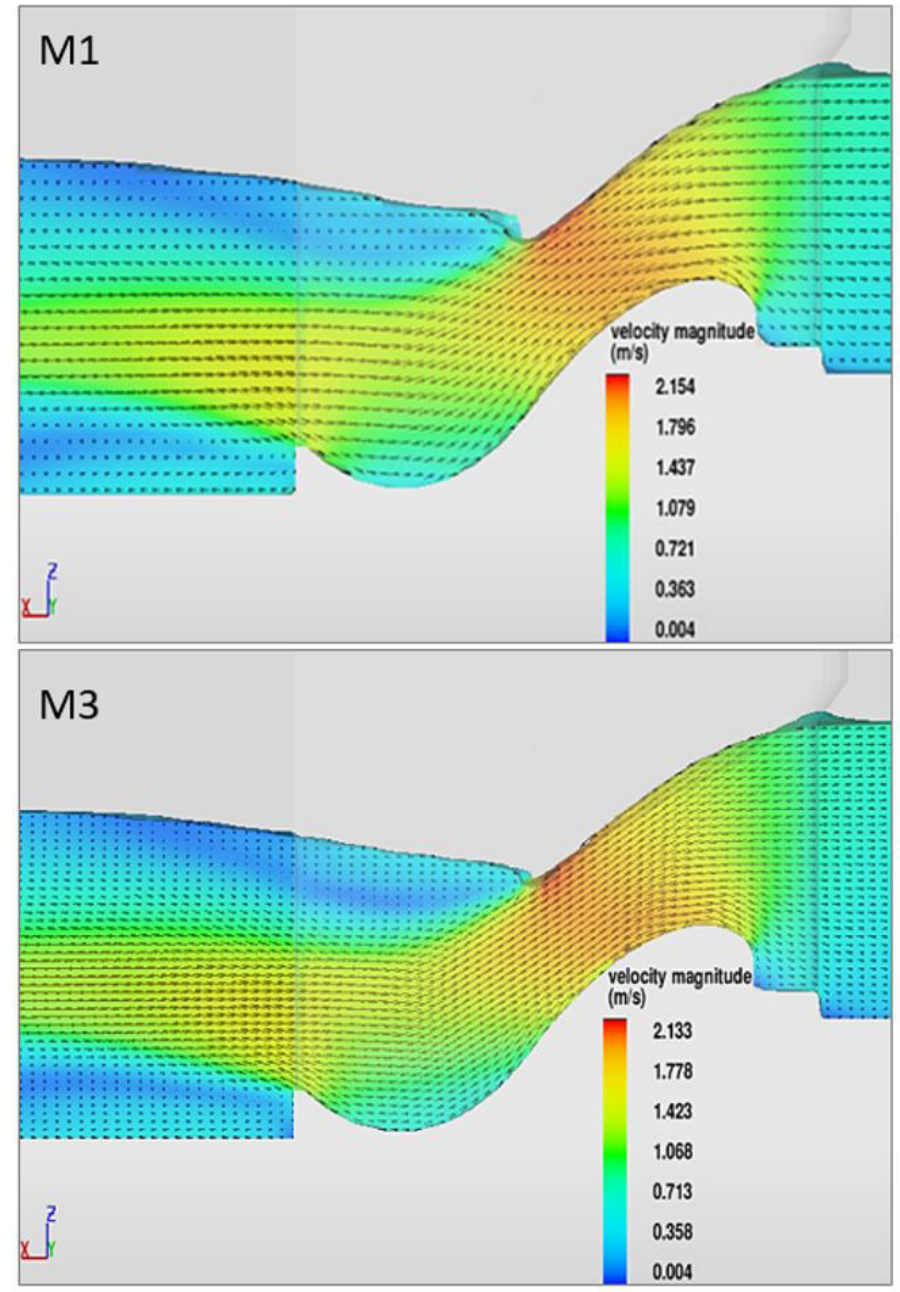

Figure 16. Pattern of flow in numerical model $-\mathrm{Q}=0.177 \mathrm{~m}^{3} / \mathrm{s}$.

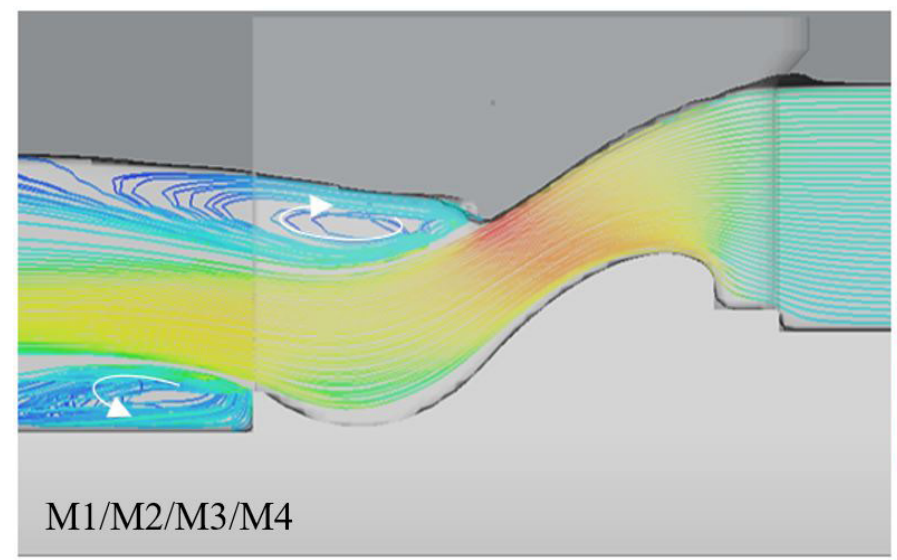

Figure 17. Stream lines in numerical model $-\mathrm{Q}=0.177 \mathrm{~m}^{3} / \mathrm{s}$.

In general, the results obtained in numerical modeling were considered satisfactory, regarding the level of water and pressures, regardless of the mesh used, there were no significant divergences for both evaluated flows. About the velocities and flow patterns, at the minimum flow the meshes M1 and M2 presented results that did not correspond to the flow pattern observed in the reduced
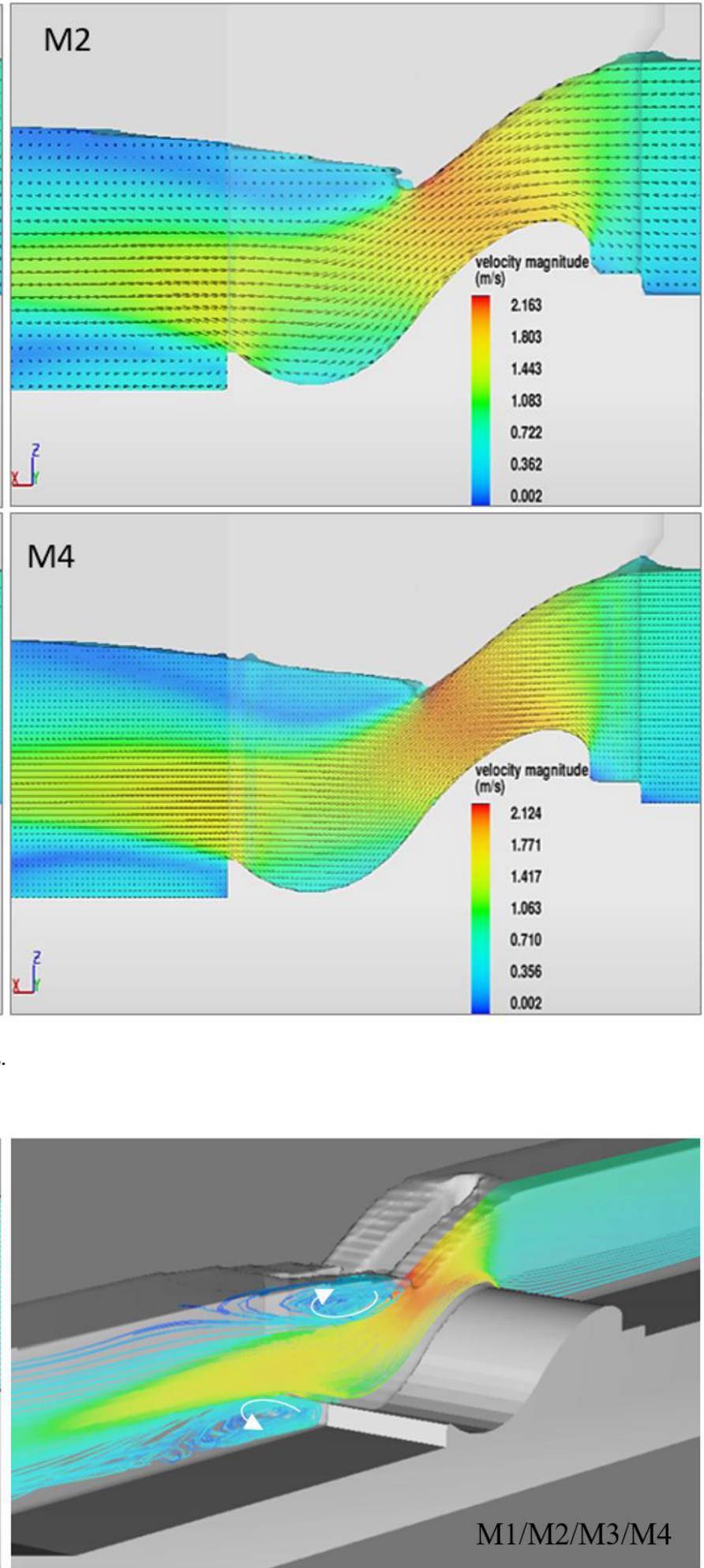

physical model. When were used the meshes M3 and M4, the numerical model was able to represent the flow pattern as expected.

For the maximum flow and regardless of the mesh used the results were considered satisfactory for water level, pressure and velocities. About the flow patterns all meshes represented adequately the observed in reduced physical model. 


\section{CONCLUSIONS}

This study has attempted to validate the use of the CFD technics in the representation of a free surface flow crossing an ogee crest spillway and roller bucket stilling basin.

It was concluded that the CFD technics is adequate for the study of this type of flow, able to reproduce the results obtained in a physical model scale regarding the definition of water free surface, to the pressure loads in the spillway profile and the qualitative aspect of the pattern flow. The qualitative evaluations of the flow pattern as regards the formation of the sink rollers located above the launching shell and the recirculation zones located immediately downstream of the terminal sill have proved satisfactory and representative just for more refined meshes. So, a computational mesh sensitivity analysis must be performed to identify and ensure the representation of all the phenomena involved. As shown in this study, the appropriate representation of the computational mesh is directly proportional to the number of elements used and computational processing time.

The methodological approach applied in this study, i.e., modeling the numerical model in the scale of the physical model, not only allowed the validation of the computational fluid dynamics techniques carried out by this work without the necessity of dealing with scale effects when comparing results from physical and numerical models, but it also presents an alternative of studies to evaluate the magnitude of the errors committed from the application of the Froude similarity criterion in the extrapolation of the results obtained in the physical model reduced to the prototype scale. Consequently, this study goes forward in the sense of bringing new proposals when designing hydraulic structures as spillways and stilling basin.

\section{ACKNOWLEDGEMENTS}

I thank my mentors for the teachings and Technology Hydraulic Center Foundation.

\section{REFERENCES}

Araujo Filho, M. F. \& Ota, J. J. (2016). Tridimensional computational modelling of a low-drop spillway. Revista Brasileira de Recursos Hidricos - RBRH, 21(2), 370-376. http://dx.doi.org/10.21168/ rbrh.v21n2.p360-376.

Aydin, M. C., \& Ozturk, M. (2009). Verification and validation of a computational fluid dynamics (CFD) model for air entrainment at spillway aerators. Canadian Journal of Civil Engineering, 36(5), 826-836. http://dx.doi.org/10.1139/L09-017.

Chanel, P. (2007). An evaluation of computational fluid dynamics for spillway modeling (Thesis). Department of Civil Engineering, University of Manitoba, Winnipeg, Canadá.

Dargahi, B. (2006). Experimental study and 3D numerical simulations for a free-overflow spillway. Journal of Hydraulic Engineering, 132(9), 899-907. http://dx.doi.org/10.1061/(ASCE)07339429(2006)132:9(899).
Dettmer, P. H. C., Ota, J. J., Fabiani, A. L. T., Araujo, A. L., \& Franco, H. C. B. (2013). Simulação numérica da capacidade de descarga de um vertedouro de Baixa Queda Afogado por Jusante. In Anais do $20^{\circ}$ Simpósio Brasileiro de Recursos Hídricos. Porto Alegre: ABRH.

Fill, G. (2011). Modelagem bidrodinâmica 3D de escoamentos em vertedouros (Dissertação de mestrado). Universidade Federal do Paraná, Curitiba.

Gessler, D. (2005). CFD modeling of spillway performance. In World Water and Environmental Resources Congress. Reston: ASCE. http://dx.doi.org/10.1061/40792(173)398.

Hirt, C. W., \& Sicilian, J. M. (1985). A porosity technique for the definition of obstacle in rectangular cell meshes. In International Conference on Numerical Ship Hydrodynamics National Academy of Science (pp. 1-19). Washington: The National Academies Press.

Johnson, M., \& Savage, B. (2006). Physical and numerical comparison of flow over ogee spillway in the presence of tailwater. Journal of Hydraulic Engineering, 132(12), 1353-1357. http://dx.doi.org/10.1061/ (ASCE)0733-9429(2006)132:12(1353).

Launder, B., \& Spalding, D. (1972). Mathematical models of turbulence. Waltham: Academic Press.

Morais, V. H. P. (2015). Modelagem numérica e experimental aplicada a um vertedouro de superfície composto por um perfil Creager e dissipador Roller Bucket (Dissertação de mestrado). Universidade Estadual de Campinas, Campinas.

Motta, V. F. (1972). Curso de teoria da semelhança (154 p ). Porto Alegre: URGS.

Naghavi, B., Esmaili, K., \& Vahid, F. K. (2011). An experimental and numerical study on hydraulic characteristics and theorical equations of circular weirs. Canadian Journal of Civil Engineering, 38(12), 1327-1334. http://dx.doi.org/10.1139/111-092.

Pelletier, D. (2010). Verification, validation, and uncertainty in computational fluids dynamics. Canadian Journal of Civil Engineering, 37(7), 1003-1113. http://dx.doi.org/10.1139/L10-032.

Rodrigues, R. C. (2002). Estudo numérico e experimental de Bacia de Dissipação (Dissertação de mestrado). Instituto Militar de Engenharia, Rio de Janeiro.

Savage, B., \& Johnson, M. (2001). Flow over ogee spillway: physical and numerical model case study. Journal of Hydraulic Engineering, 127(8), 640-649. http://dx.doi.org/10.1061/(ASCE)07339429(2001)127:8(640).

Shames, H. I. (1973). Mecânica dos fuidos (2 v.). São Paulo: Edgar Blucher.

Tadayon, R., \& Ramamurthy, A. S. (2009). Turbulence modeling of flows over circular spillways. Journal of Irrigation and Drainage Engineering, 135(4), 493-498. http://dx.doi.org/10.1061/(ASCE) IR.1943-4774.0000012.

Turan, C., Carrica, P. M., Lyons, T., Hay, D., \& Weber, L. (2008). Study of the free surface flow on an ogee-crested fish bypass. 
Journal of Hydraulic Engineering, 134(8), 1172-1175. http:/ / dx.doi. org/10.1061/(ASCE)0733-9429(2008)134:8(1172).

Versteeg, H. K., \& Malalasekera, W. (1995). An introduction to computational fluid dynamics. The finite volume method. Harlow: Longman Scientific \& Technical.

Zeng, J., Zhang, L., Ansar, M., Damisse, E., \& Castro, J. A. G. (2016). Applications of computational fluid dynamics to flow ratings at ptototype spillways and weirs. I: data generation and validation. Journal of Irrigation and Drainage Engineering, 143(1):04016072. http:/ / dx.doi.org/10.1061/(ASCE)IR.1943-4774.0001112.

\section{Authors contributions}

Vitor Hugo Pereira de Morais: Bibliographical review, development and application of methodology, analysis and discussion results.

Tiago Zenker Gireli: Development of methodology, analysis and discussion of results.

Paulo Vatavuk: Development of methodology, analysis and discussion of results. 